\title{
Angular Photogrammetric Analysis of the Facial Profile of the Adult Bangladeshi Garo
}

\author{
Mussammat Afsana Ferdousi ${ }^{1}$, Abdullah Al Mamun ${ }^{2}$, Laila Anjuman Banu ${ }^{3 *}$, Sudip Paul ${ }^{4}$ \\ ${ }^{1}$ Department of Anatomy, Tairunnessa Memorial Medical College and Hospital, Dhaka, Bangladesh \\ ${ }^{2}$ Department of Microbiology, North Bengal Medical College, Sirajganj, Bangladesh \\ ${ }^{3}$ Department of Anatomy, Bangabandhu Sheikh Mujib Medical University, Dhaka, Bangladesh \\ ${ }^{4}$ Department of Biochemistry and Molecular Biology, Jahangirnagar University, Dhaka, Bangladesh \\ Email: *dr.lailabanu@gmail.com
}

Received May 22 ${ }^{\text {nd }}, 2013$; revised June $25^{\text {th }}, 2013$; accepted July $21^{\text {st }}, 2013$

Copyright (C) 2013 Mussammat Afsana Ferdousi et al. This is an open access article distributed under the Creative Commons Attribution License, which permits unrestricted use, distribution, and reproduction in any medium, provided the original work is properly cited.

\begin{abstract}
The analysis of facial soft tissue from the photographic records gives information about the standard normative values of different facial parameters of a specific population group, helps in the diagnosis of any abnormalities of face and also helps for the treatment plan of patients undergoing orthodontic treatment or facial plastic surgery. The aim of the present study was to measure some craniofacial angles of the Bangladeshi Garo males and females on standardized facial profile photographs and compare them with each other and with norms of different ethnic group proposed by the other investigators. The study was carried out with a total number of 100 Christian Garo adult male and female subjects. Statistical analysis showed that the females had significantly higher values than the males in three facial angles $(p<0.05)$ : the nasofrontal angle $\left(\mathrm{G}-\mathrm{N}-\right.$ Pro, females $=137.97^{\circ} \pm 4.80^{\circ} ;$ males $\left.=129.57^{\circ} \pm 7.96^{\circ}\right)$, the nasomental angle $(\mathrm{N}-$ Prn-Pg, females $=132.79^{\circ} \pm 5.10^{\circ}$; males $\left.=129.75^{\circ} \pm 7.32^{\circ}\right)$ and the angle of facial convexity $(\mathrm{G}-\mathrm{Sn}-\mathrm{Pg}$, females $=169.26^{\circ} \pm 4.43^{\circ}$; males $\left.=158.65^{\circ} \pm 12.17^{\circ}\right)$ but no differences between the nasofacial $(\mathrm{G}-\mathrm{Pg} /$ $\mathrm{N}-\mathrm{Prn})$ and nasolabial angle (Cm-Sn-Ls). Findings from the present study might help to establish a distinct facial profile trait for the Garo population.
\end{abstract}

Keywords: Photogrammetric Analysis; Facial Angle; Garo Population

\section{Introduction}

The face is the most attractive and variable part of the human body. The variability and beautifulness of the face are expressed by different sizes and shapes of individual features of different parts of the face and also by different facial angles. As face is the entity which gives us the perception of individuality of human being and of gender differences, different craniofacial parameters help in identifying people having different physical characteristics, diagnosing people having craniofacial abnormality related to congenital or genetic cause and differentiating between males and females. Various methods have been used to evaluate facial characteristics such as craniofacial anthropometry (Kolar \& Salter, 1997), photogrammetry (Fernandez-Riveiro et al., 2003; Kale-Varlik, 2003; Anicy-Milosivecy et al., 2008; Malkoc et al., 2009; Anibor \& Okumagba, 2010; Reddy et al., 2011; Wamalwa et al., 2011), cephalometric radiography (McIntyre \& Mossey, 2003), stereophotogrammetry (Sforza \& Ferrario, 2006), computed tomography and laser scanning (AlKhatib, 2010).

Anthropometric measurements on photographs are called photogrammetry. Stoner (1955) and Fernandez-Riveiro et al. (2003) standardized the photographic technique and record taking in natural head position (NHP) and gave average values for White adults, whereas Arnett and Bergman (1993) also took

\footnotetext{
*Corresponding author.
}

records in NHP and described the facial profile using the angle of facial convexity.

Craniofacial photogrammetry is a new field in Bangladesh. It is simple to be applied and is relatively noninvasive and low cost method. It avoids inconvenience of the participants and also saves valuable time. It provides a permanent record for the actual appearance of the participants. As the outline of the photographs do not change and the soft tissue becomes incomepressible on the bone, so the data obtained from the analysis of angular photogrammetric profile can provide the maxillofacial and plastic surgeons, orthodontists and other clinicians with a way of understanding problems associated with various soft tissue segments of the facial region and also can help in setting aesthetic treatment plans for the patients.

Populations vary genetically and geographically in their craniofacial features. Therefore, a single standard of anthropometric variables is not appropriate for being applied to diverse racial and ethnic groups. Though Bangladesh is a relatively small country, people of different religions and ethnic groups live here and these different groups have differences in their physical characteristics. The Garo community is one of the major tribes in Bangladesh. The people from the Garo tribe have different physical characteristics from those of the Bengali population. Broadly speaking, they carry the racial characteristics of the Mongoloids (Banglapedia, 2011). Study on Angular photogrammetric profile analysis of the Garo tribal population is 
scanty, especially on the measurements like facial profile angles and sexual differences.

Measurement of the different craniofacial variables is being considered as important for studying human growth because facial proportions change with age, for studying sexual differences as sex differences are presented by variations in skeletal dimensions and muscle development and also for clinical treatments as normative value of craniofacial dimensions help in determining abnormality and thus treatment planning (Kolar \& Salter, 1997). So, the results of this study were expected to be useful for the anatomists, physical anthropologists, genetic counselors, forensic scientists, beauticians as well as plastic and reconstructive surgeons.

\section{Materials and Methods}

\section{Study Participants}

A total of 100 adult Bangladeshi Christian Garo (50 males and 50 females) participants aged between 25 and 45 years residing at Dhaka city were enrolled in the study and the analysis of the data were done in the Department of Anatomy, Bangabandhu Sheikh Mujib Medical University (BSMMU), Dhaka from July 2010 to June 2011. They were without any history of acquired or genetic craniofacial anomalies. Participants were considered to be the "Garo" if there two grandparents were of Garo origin. Among the Garo, only Christians and adults were decided to be selected for avoiding possible differences with age or those arising from habits related to specific religions. The research proposal was approved by the Ethical Review Committee (ERC) of BSMMU. Then consent was obtained from each participant by taking her/his signature on the written consent form.

\section{Photographic Setup}

All right profile photographs were taken with a Kodak Easy Share Z 710 digital camera, with $10 \mathrm{X}$ optical zoom and at a 7.1 megapixel resolution. A blue color curtain was used as a background, and flash mode was also used.

\section{Photograph Taking}

To take a good image, the camera was positioned approximately $1.0-1.5$ meter distance from the participant and was raised to the ear level of the participant to provide good quality of image and to prevent distortion of the face (Ozkul et al., 2009). All the photographs were taken with the participants sitting in a relaxed position with their heads held in the natural head position (Fernandez-Riveiro et al., 2003).

\section{Photograph Analysis}

Analysis of the facial photographs was done by a computer software program named Adobe Photoshop CS 4 Extended (Figures 1-6). All the measurements were taken twice and recorded in the corresponding data form.

\section{Statistical Analysis}

Computer assisted analysis of the right lateral facial photographs was done by using a computer based software program Statistical Package for Social Sciences (SPSS-version 17.0).

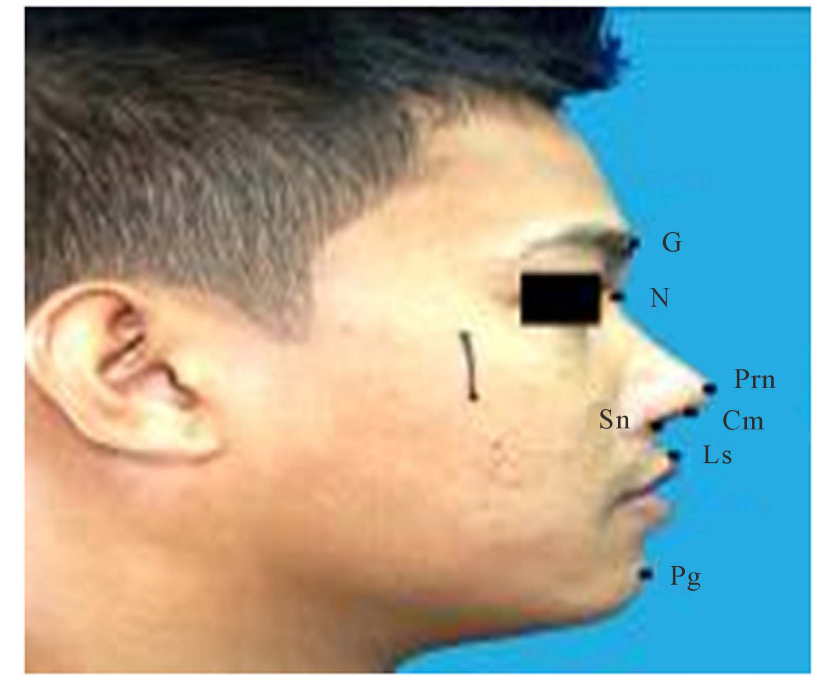

Figure 1.

Landmarks used in this investigation: G, glabella; N, nasion; Prn, pronasale; $\mathrm{Cm}$, columella; $\mathrm{Sn}$, subnasale; Ls, labial superior; $\mathrm{Pg}$, pogonion.

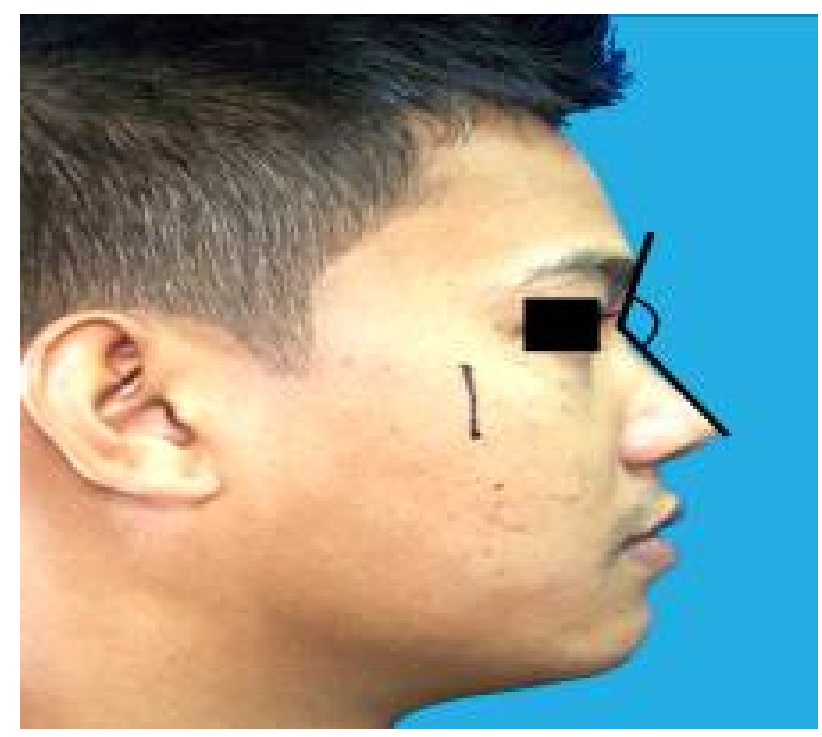

Figure 2.

Nasofrontal angle (G-N-Prn).

The ranges and mean \pm standard deviations (SDs) were calculated for each angle and unpaired Student's t-test was calculated to find out the differences of facial angles between the Garo males and females. A $p$ value $\leq 0.05$ was set as being statistically significant. Index of sexual dimorphism was also calculated (Hwang et al., 1995).

\section{Results}

Descriptive statistical data including mean, maximum, minimum, and standard deviations for the photogrammetric angular measurements together with the results of the Student's t-test comparing male and female measurements are shown in Table 1.

Statistically significant sex differences were found in three of the five angles analyzed: all angles that suggested gender differences were wider in females: the nasofrontal angle (G-N- 
Table 1.

Data of craniofacial angles for the males and females of Garo population.

\begin{tabular}{|c|c|c|c|c|c|}
\hline \multirow{2}{*}{ Craniofacial angles (degree) } & \multirow{2}{*}{ Sex } & \multicolumn{2}{|c|}{ Value (degree) } & \multirow{2}{*}{$P$ value } & \multirow{2}{*}{ Index of sexual dimorphism } \\
\hline & & Ranges & Mean ( \pm SD) & & \\
\hline \multirow{2}{*}{ Nasofrontal angle } & Female & $127.80-146.10$ & $137.96( \pm 4.79)$ & \multirow{2}{*}{$0.00^{*}$} & \multirow{2}{*}{-6.48} \\
\hline & Male & $107.80-142.05$ & $129.56( \pm 7.96)$ & & \\
\hline \multirow{2}{*}{ Nasofacial angle } & Female & $30.25-48.50$ & $38.67( \pm 4.05)$ & \multirow{2}{*}{0.07} & \multirow{2}{*}{3.98} \\
\hline & Male & $32.90-51.10$ & $40.27( \pm 4.54)$ & & \\
\hline \multirow{2}{*}{ Nasomental angle } & Female & $117.90-145.50$ & $132.79( \pm 5.10)$ & \multirow{2}{*}{$0.02^{*}$} & \multirow{2}{*}{-2.34} \\
\hline & Male & $99.50-142.50$ & $129.75( \pm 7.32)$ & & \\
\hline \multirow{2}{*}{ Nasolabial angle } & Female & $74.50-110.50$ & $91.92( \pm 8.90)$ & \multirow{2}{*}{0.78} & \multirow{2}{*}{-0.70} \\
\hline & Male & $66.70-114.85$ & $91.28( \pm 12.98)$ & & \\
\hline \multirow{2}{*}{ Angle of facial convexity } & Female & $164.83-172.69$ & $169.26( \pm 4.43)$ & \multirow{2}{*}{$0.00^{*}$} & \multirow{2}{*}{-6.72} \\
\hline & Male & $146.48-170.82$ & $158.65( \pm 12.17)$ & & \\
\hline
\end{tabular}

Note: Unpaired Student's t test was done to test the significance of difference between the males and the females; "Statistically significant; "Index of sexual dimorphism = [(Male Mean - Female mean)/Male mean $] \times 100$.

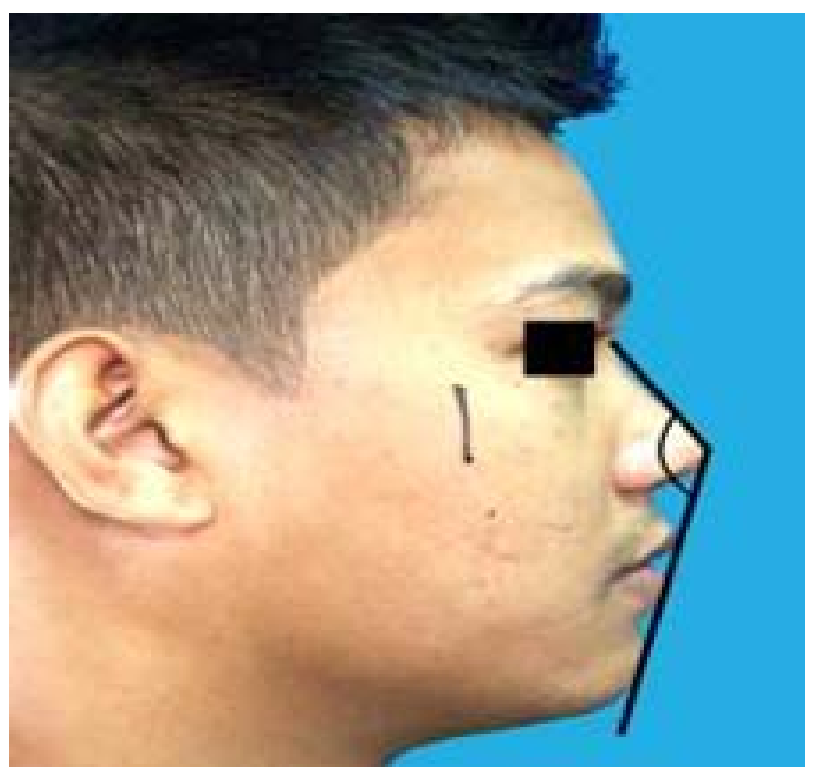

Figure 3.

Nasomental angle (N-Prn-Pg).

Pro, females $=137.97^{\circ} \pm 4.80^{\circ}$; males $=129.57^{\circ} \pm 7.96^{\circ}$, the nasomental angle $\left(\mathrm{N}-\mathrm{Prn}-\mathrm{Pg}\right.$, females $=132.79^{\circ} \pm 5.10^{\circ}$; males $\left.=129.75^{\circ} \pm 7.32^{\circ}\right)$ and the angle of facial convexity (G-Sn-Pg, females $=169.26^{\circ} \pm 4.43^{\circ}$; males $=158.65^{\circ} \pm 12.17^{\circ}$, whereas nasofacial angle was wider in males without significant sexual differences.

The relationship between the columella and the upper lip, analyzed by the nasolabial angle (Cm-Sn-Ls), showed large variability from 36.70 to 114.85 degrees for males and from 74.50 to 110.50 degrees for females. Large variability was also noted in the angle of facial convexity characterized by high SDs.

According to the index of sexual dimorphism, the highest level of sexual differences among the angles of the face was seen in the angle of facial convexity and the nasofrontal angle. This index was negative (-ve) when the mean value of the females was more than that of the males.

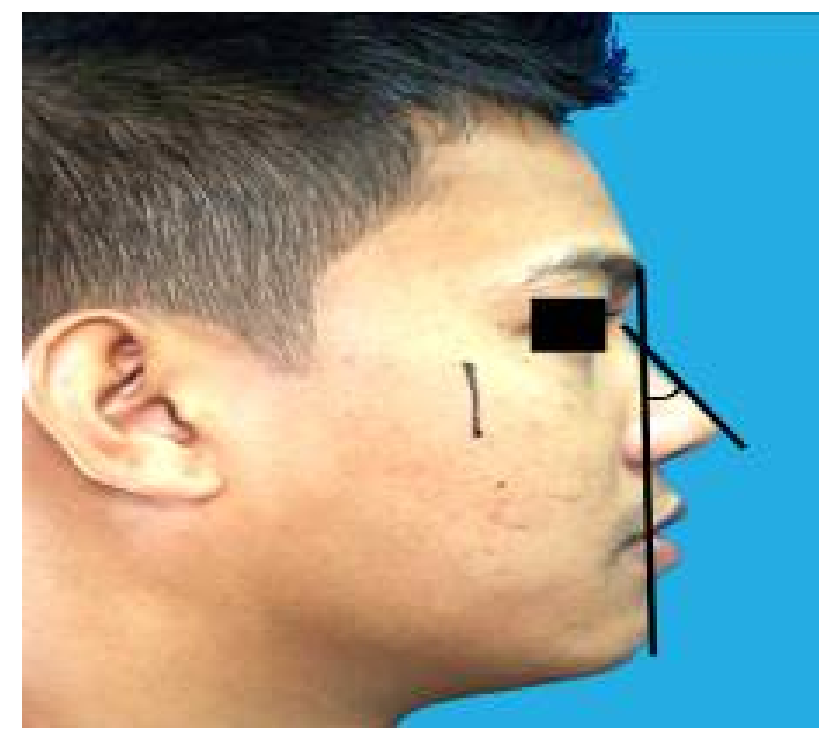

Figure 4.

Nasofacial angle (G-Pg/N-Prn).

\section{Discussion}

Photogrammetric analysis had advantages in facial profile analysis especially on angular measurements, as they are not affected by photographic enlargement, non-invasive and commonly used method to investigate pre- and post-operative changes and provides a permanent record of patients (Sforza \& Ferrario, 2006). Compared with other methods, photogrammetric analysis does not require expensive or complex equipment and offers digital results that are easily evaluated using computer software. Furthermore, there is no radiation exposure, so it is ethically more acceptable to develop population norms through population-based studies.

The higher values (Table 1) for the females in this study could be explained by the fact that in general the facial contours of female subjects were softer than those of males, especially in the area of the nose, lips, and chin (Anicy-Milosivecy et al., 2008). 


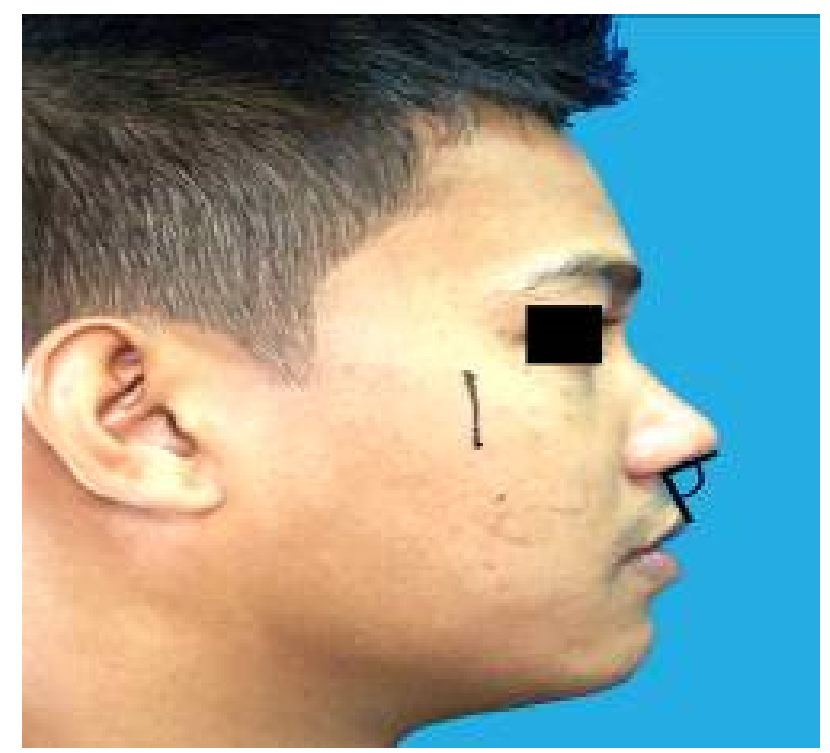

Figure 5.

Nasolabial angle (Cm-Sn-Ls).

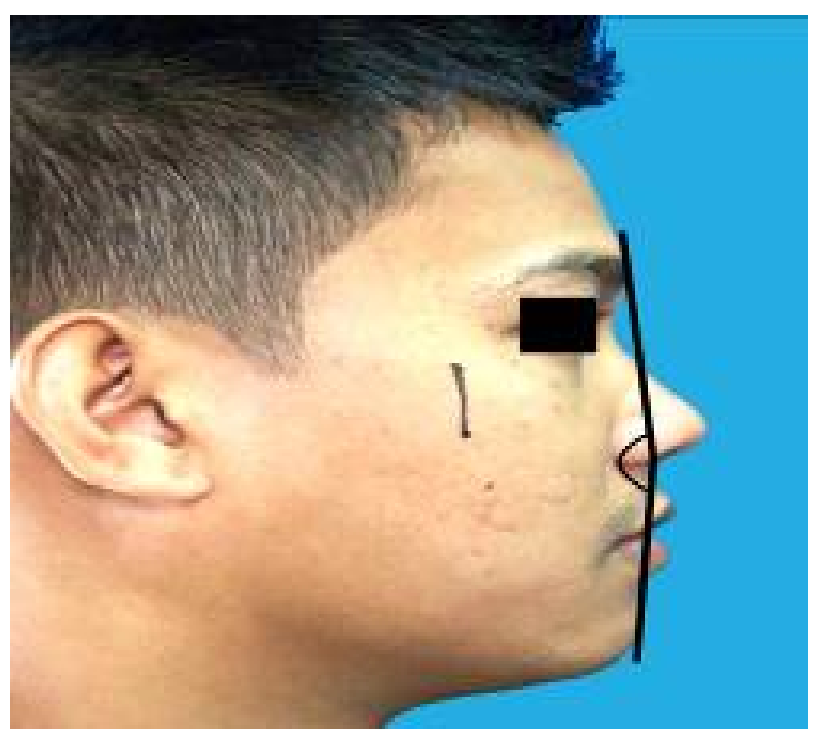

Figure 6.

Angle of the facial convexity (G-Sn-Pg).

The nasofrontal angle (G-N-Prn) showed significant sex differences in the adult Garo and the angle was wider in females. This is in agreement to the findings by Reddy et al. (2011) in the North Indian population $\left(136.71^{\circ} \pm 3.64^{\circ}\right.$ in males and $144.33^{\circ} \pm 1.75^{\circ}$ in females), Fernandez-Riveiro et al. (2003) for Spanish $\left(138.57^{\circ} \pm 6.81^{\circ}\right.$ in males and $141.98^{\circ} \pm 6.06^{\circ}$ in females), Anic-Milosevic et al. (2008) for Croatian (136.38 \pm $6.71^{\circ}$ in males and $139.11^{\circ} \pm 6.35^{\circ}$ in females) and Wamalwa et al. (2011) for Kenyans $\left(132.44^{\circ} \pm 6.91^{\circ}\right.$ in males and $137.97^{\circ} \pm$ $5.21^{\circ}$ in females). However, Malkoc et al. (2009) found no sex differences in this angle $\left(146.03^{\circ} \pm 8.19^{\circ}\right.$ in males and $148.61^{\circ}$ $\pm 6.66^{\circ}$ in females). Anibor and Okumagba (2010) found higher mean male value than the female in Negroid population $\left(132.0^{\circ}\right.$ $\pm 7.50^{\circ}$ in males and $137.70^{\circ} \pm 7.6^{\circ}$ in females). The lower mean value of nasofrontal angle may be attributed to prominent glabella in the male (Mowlavi et al., 2004).
The mean value of nasofacial angle (G-Pg/N-Prn) found in the adult Garo population $\left(40.27^{\circ} \pm 4.54^{\circ}\right.$ in males and $38.67^{\circ} \pm$ $4.05^{\circ}$ in females) is more in comparison to the values given by Reddy et al. (2011) $\left(34.38^{\circ} \pm 1.77^{\circ}\right.$ in males and $33.69^{\circ} \pm 1.37^{\circ}$ in females) but larger than Anicy-Milosivecy et al. (2008) $\left(29.53^{\circ} \pm 2.51^{\circ}\right.$ in males and $30.36^{\circ} \pm 2.38^{\circ}$ in females $)$. No significant sexual dimorphism was observed. Higher nasofacial angle suggests that the projection of the nose is more (Wamalwa et al., 2011).

The average value of nasomental angle (N-Prn-Pg) found in the Garo $\left(129.75^{\circ} \pm 7.32^{\circ}\right.$ in males and $132.79^{\circ} \pm 5.10^{\circ}$ in females) is similar to the North Indian population $\left(127.71^{\circ} \pm\right.$ $1.97^{\circ}$ in males and $127.11^{\circ} \pm 1.81^{\circ}$ in females) and Caucasian population $\left(130.47^{\circ} \pm 3.73^{\circ}\right.$ in males and $130.19^{\circ} \pm 3.47^{\circ}$ in females) (Reddy et al., 2011; Anicy-Milosivecy et al., 2008). Significant sexual dimorphism was also observed.

The nasolabial angle (Cm-Sn-Ls), evaluating the relationship of the nasal base and upper lip, is one of the measurements with greater clinical relevance during orthodontic diagnosis and treatment planning because its magnitude depends on the anteroposterior position and inclination of the upper anterior teeth, and it can be altered by orthodontics or orthognathic surgery (Wamalwa et al., 2011). The mean value of nasolabial angle $(\mathrm{Cm}-\mathrm{Sn}-\mathrm{Ls})$ found in the Garo $\left(91.28^{\circ} \pm 12.98^{\circ}\right.$ in males and $91.92^{\circ} \pm 8.90^{\circ}$ in females) is less than that in North Indian population $\left(102.32^{\circ} \pm 4.69^{\circ}\right.$ in males and $101.50^{\circ} \pm 4.39^{\circ}$ in females), Turkish population $\left(101.09^{\circ} \pm 10.19^{\circ}\right.$ in males and $102.94^{\circ} \pm 10.43^{\circ}$ in females), White European population $\left(105.2^{\circ} \pm 13.28^{\circ}\right.$ in males and $107.57^{\circ} \pm 8.5^{\circ}$ in females $)$ and Caucasian population $\left(105.42^{\circ} \pm 9.52^{\circ}\right.$ in males and $109.39^{\circ} \pm$ $7.84^{\circ}$ in females) (Reddy et al., 2011; Malkoc et al., 2009; Fernández-Riveiro et al., 2003; Anicy-Milosivecy et al., 2008). Significant sexual dimorphism was not observed between the males and females.

The average value of facial convexity angle (G-Sn-Pg) found in the Garo $\left(158.65^{\circ} \pm 12.17^{\circ}\right.$ in the males and $169.26^{\circ} \pm 4.43^{\circ}$ in the females) is similar to that in the North Indian population $\left(168.54^{\circ} \pm 3.23^{\circ}\right.$ in males and $166.64^{\circ} \pm 4.09^{\circ}$ in females $)$ and White European population $\left(168.2^{\circ} \pm 4.96^{\circ}\right.$ in males and $167.0^{\circ}$ $\pm 5.36^{\circ}$ in females) while slightly less than the values in Turkish population $\left(170.60^{\circ} \pm 6.15^{\circ}\right.$ in males and $168.78^{\circ} \pm 5.44^{\circ}$ in females) and Caucasian population $\left(168.78^{\circ} \pm 4.97^{\circ}\right.$ in males and $169.05^{\circ} \pm 4.69^{\circ}$ in females) (Reddy et al., 2011; Malkoc et al., 2009; Fernández-Riveiro et al., 2003; Anicy-Milosivecy et al., 2008). Significant sexual dimorphism was observed between the males and females.

\section{Conclusion}

It was assumed that a study on the facial angle measurements on the Garo population of Bangladesh would contribute to the establishment of standardized normal values for the population. It would also help in understanding how this population stands anthropometrically among the various populations of the world indicating the variations it shows from different other populations. So, more research is needed for testing the accuracy of photogrammetric method in Bangladesh.

\section{Acknowledgements}

The authors would like to thank Dr. Khondker Manzare Shamim, Professor and Chairman, Department of Anatomy, Bangabandhu Sheikh Mujib Medical University for his constant gui- 
dance and advice that make this work possible.

\section{REFERENCES}

Al-Khatib, A. R. (2010). Facial three dimensional surface imaging: An overview. Archives of Orofacial Sciences, 1, 1-8.

Anibor, E., \& Okumagba, M. T. (2010). Photometric facial analysis of the Urhobo ethnic group in Nigeria. Archives of Applied Science Research, 3, 28-32.

Anicy-Milosivecy, S., Lapter-Varga, M., \& Slaj, M. (2008). Analysis of the soft tissue facial profile by means of angular measurements. European Journal of Orthodontics, 2, 135-140.

http://dx.doi.org/10.1093/ejo/cjm116

Arnett, G. W., \& Bergman, R. T. (1993). Facial keys to orthodontic diagnosis and treatment planning-Part I. American Journal of Orthodontics and Dentofacial Orthopedics, 103, 299-312. http://dx.doi.org/10.1016/0889-5406(93)70010-L

Banglapedia (2011). Garo people. http://www.banglapedia.org/HT/G_0043.HTM

Fernandez-Riveiro, P., Smyth-Chamosa, E., Suarez-Quintanilla, D., \& Suarez-Cunqueiro, M. (2003). Angular photogrammetric analysis of the soft tissue facial profile. European Journal of Orthodontics, 25, 393-399. http://dx.doi.org/10.1093/ejo/25.4.393

Hwang, Y., Lee, K. H., Choi, B. Y., Lee, K. S., Lee H. Y., Sir, W. S. et al. (1995). Study on the Korean adult cranial capacity. Journal of Korean Medical Science, 4, 239-242.

Kale-Varlik, S. (2003). Angular photogrammetric analysis of the soft tissue facial profile of Anatolian Turkish adults. The Journal of Craniofacial Surgery, 6, 1481-1486.

Kolar, J. C., \& Salter, E. M. (1997). Craniofacial anthropometry: Practical measurement of the head and face for clinical, surgical and research use. Springfield, Illinois: Charles C Thomas, Publisher Ltd.
Malkoc, S., Demir, A., \& Uysal, T. (2009). Angular photogrammetric analysis of the soft tissue facial profile of Turkish adults. European Journal of Orthodontics, 31, 174-179. http://dx.doi.org/10.1093/ejo/cjn082

McIntyre, G. T., \& Mossey, P. A. (2003). Size and shape measurement in contemporary cephalometrics. European Journal of Orthodontics, 25, 231-242. http://dx.doi.org/10.1093/ejo/25.3.231

Mowlavi, A., Meldrum, D. G., \& Wilhelmi, B. J. (2004). Implications for nasal recontouring: Nasion position preferences as determined by a survey of White North Americans. Aesthetic Plastic Surgery, 27, 438-445.

Ozkul, T., Ozkul, M. H., Akhtar, R., Al-Kaabi, F., \& Jumaia, T. (2009). A software tool for measurement of facial parameters. The Open Chemical and Biomedical Methods Journal, 2, 69-74. http://dx.doi.org/10.2174/1875038900902010069

Reddy, M., Ahuja, N. K., Raghav, P., Kundu, V., \& Mishra V. A. (2011). Computer-assisted angular photogrammetric analysis of the soft tissue facial profile of North Indian adults. The Journal of Indian Orthodontic Society, 3, 119-123. http://dx.doi.org/10.5005/jp-journals-10021-1021

Sforza, C., \& Ferrario, V. F. (2006). Soft-tissue facial anthropometry in three dimensions: From anatomical landmarks to digital morphology in research, clinics and forensic anthropology. Journal of Anthropological Sciences, 84, 97-124.

Stoner, M. M. (1955). A photometric analysis of the facial profile. American Journal of Orthodontics, 41, 453-469. http://dx.doi.org/10.1016/0002-9416(55)90156-1

Wamalwa, P., Amisi, S. K., \& Chen, S. (2011). Angular photogrammetric comparison of the soft-tissue facial profile of Kenyans and Chinese. The Journal of Craniofacial Surgery, 3, 1064-1072. http://dx.doi.org/10.1097/SCS.0b013e31821075d8 